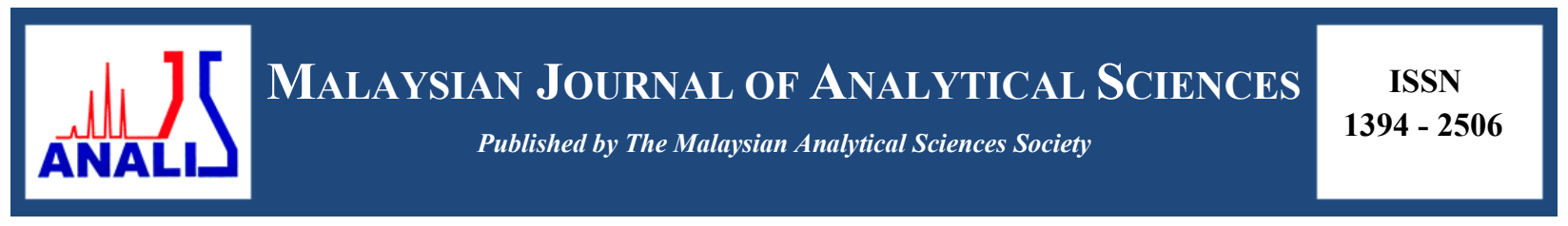

\title{
A COMPARATIVE STUDY ON THE INHIBITORY ACTION OF SOME GREEN INHIBITORS ON THE CORROSION OF MILD STEEL IN HYDROCHLORIC ACID MEDIUM
}

\author{
(Kajian Perbandingan Tindakan Rencatan oleh Perencat Hijau ke atas Pengaratan Keluli Lembut \\ di dalam Medium Asid Hidroklorik) \\ Moorthy Shyamala ${ }^{1} *$ and Arthanas Arulanantham ${ }^{2}$ \\ ${ }^{1}$ Department of Chemistry, \\ Government College of Technology, Coimbatore-641013, Tamil Nadu, India \\ ${ }^{2}$ Department of Chemistry, \\ S.N.S College of Technology, Coimbatore-641013, Tamil Nadu, India \\ *Corresponding author: shyamphd@yahoo.com
}

Received: 24 February 2015; Accepted: 9 February 2017

\begin{abstract}
The inhibitive action of the extracts of three green inhibitors namely Adathoda vasica, Eclipta alba and Centella asiatica were investigated. Polarization method indicates that the plant extracts are under mixed control i.e promoting retardation of both anodic and cathodic reactions. The impedance method reveals that charge-transfer process controls the corrosion of mild steel. The plant-extracts obeys Langmuir adsorption isotherm. Kinetics and reason for the corrosion inhibition or the nature of adsorption is clearly shown. Physisorption mechanism has been proposed for the inhibition action of these plant extracts. The protective film formed on the surface was confirmed by Scanning Electron Microscopy (SEM). From hydrogen permeation method, all the plant extracts were able to reduce the permeation current. Results obtained in all the methods are very much in good agreement with increasing inhibition efficiency in the order: Eclipta alba $>$ Adathoda vasica $>$ Centella asiatica. Among the three plant extracts studied, the maximum inhibition efficiency was found in Eclipta alba which showed $99.6 \%$ inhibition efficiency at $8.0 \% \mathrm{v} / \mathrm{v}$ concentration of the extract.
\end{abstract}

Keywords: mild steel, corrosion inhibition, plant-extracts, hydrochloric acid, physisorption

\begin{abstract}
Abstrak
Tindakan perencatan oleh tiga ekstrak perencat hijau iaitu Adathoda vasica, Eclipta alba dan Centella asiatica telah dikaji. Kaedah polarisasi menunjukkan bahawa ekstrak tumbuhan di bawah kawalan campuran akan menghasilkan tindak balas perencatan bagi kedua-dua anod dan katod. Kaedah galangan mendedahkan bahawa proses pemindahan cas mengawal kakisan terhadap keluli lembut. Bahan ekstrak tumbuhan mematuhi penjerapan isoterma Langmuir. Kinetik dan sebab bagi perencatan kakisan atau sifat penjerapan jelas dapat ditunjukkan. Tindakan perencatan dari ekstrak tumbuhan adalah dicadangkan sebagai mekanisma serapan fizikal. Filem pelindung yang terbentuk di permukaan telah disahkan melalui mikroskopi elektron pengimbasan (SEM). Melalui kaedah penyerapan hidrogen, semua ekstrak tumbuhan dikenalpasti dapat mengurangkan penelapan arus. Keputusan yang diperolehi dalam semua kaedah amat bersetuju dengan peningkatan kecekapan rencatan adalah mengikut tertib iaitu Eclipta alba $>$ Adathoda vasica $>$ Centella asiatica. Di antara ketiga-tiga ekstrak tumbuhan yang dikaji, kecekapan rencatan maksimum diperolehi dari Eclipta alba iaitu $99.6 \%$ pada $8.0 \%$ v/v kepekatan ekstrak.
\end{abstract}

Kata kunci: keluli lembut, perencat kakisan, ekstrak tumbuhan, asid hidroklorik, serapan fizikal 


\section{Shyamala \& Arulanantham: A COMPARATIVE STUDY ON THE INHIBITORY ACTION OF SOME GREEN INHIBITORS ON THE CORROSION OF MILD STEEL IN HYDROCHLORIC ACID MEDIUM}

\section{Introduction}

Mild steel are widely used in boilers, motor car bodies, machines, gears, pipes, tanks and in most of the chemical industries. Hydrochloric acid and sulphuric acids are the medium generally used for pickling mild steel. About $90 \%$ of pickling problems can be solved by introducing appropriate pickling inhibitor to the medium. The recent and growing trend is using plant extracts as corrosion inhibitor on mild steel in acid medium due to their biodegradability, ecofriendliness, less toxicity, cost effectiveness, easy availability, environmentally safe, soluble and highly stable nature in acidic solutions. Owing to strict environmental legislation, emphasis is being focused on development of naturally occurring substances as corrosion inhibitors. Recently, many plant extracts have been reported to be very effective corrosion inhibitors for the protection of mild steel in acidic media [1 - 4]. In this study, the inhibition effect of the extracts of three green inhibitors namely Adathoda vasica (Adathodai), Eclipta alba (Karisilankani) and Centella asiatica (Vallarai) on the corrosion of mild steel in $1 \mathrm{~N}$ hydrochloric acid was investigated using electrochemical and non-electrochemical methods.

\section{Preparation of mild steel specimen}

\section{Materials and Methods}

Mild steel strips were mechanically cut into strips of size $4.5 \mathrm{~cm} \times 2 \mathrm{~cm} \times 0.2 \mathrm{~cm}$ containing the composition of $0.14 \% \mathrm{C}, 0.35 \% \mathrm{Mn}, 0.17 \% \mathrm{Si}, 0.025 \% \mathrm{~S}, 0.03 \% \mathrm{P}$ and the remainder is $\mathrm{Fe}$ and provided with a hole of uniform diameter to facilitate suspension of the strips in the test solution for weight loss method. For electrochemical studies, mild steel strips of the same composition but with an exposed area of $1 \mathrm{~cm}^{2}$ were used. Mild steel strips were mechanically polished with emery papers of $1 / 0$ to $4 / 0$ grades and subsequently degreased with trichloroethylene or acetone and finally with de-ionized water and stored in the desiccator. Accurate weight of the samples was taken using electronic balance.

\section{Preparation of the green inhibitors}

The leaves of the Adathoda vasica, Eclipta alba and Centella asiatica were taken and cut into small pieces and they were dried in an air oven at $80^{\circ} \mathrm{C}$ for 2 hours and ground well into powder. An amount $10 \mathrm{~g}$ of the sample was refluxed in $100 \mathrm{~mL}$ of distilled water for 1 hours. The refluxed solution was then filtered carefully and the filtrate volume was made up to $100 \mathrm{~mL}$ using double distilled water which is the stock solution and the concentration of the stock solution is expressed in terms of \% (v/v). From the stock solution, $2 \%-10 \%$ concentration of the extracts was prepared using $1 \mathrm{~N}$ hydrochloric acid.

\section{Weight loss method}

The pretreated specimens' initial weights were noted and were immersed in the experimental solution (in triplicate) with the help of glass hooks at $30^{\circ} \mathrm{C}$ for a period of 3 hours. The experimental solution used was $1 \mathrm{~N} \mathrm{HCl}$ in the absence and presence of various concentrations of the plant extracts. After three hours, the specimens were taken out, washed thoroughly with distilled water, dried completely and their final weights were noted. From the initial and final weights of the specimen, the loss in weight was calculated and tabulated. From the weight loss, the corrosion rate (mmpy), inhibition efficiency (\%) and surface coverage $(\theta)$ of plant extracts was calculated using the equation $1-3$ as shown below:

$$
\text { Corrosion rate (mmpy) }=\mathrm{KW} / \mathrm{ATD}
$$

where $\mathrm{K}=8.76 \times 10^{4}$ (constant), $\mathrm{W}=$ weight loss in $\mathrm{g}, \mathrm{A}=$ area in sq.cm, $\mathrm{T}=$ Time in hours and $\mathrm{D}=$ density in gm/ cu.cm (7.86).

$$
\begin{aligned}
& \text { Inhibition efficiency }(\%)=\left(\mathrm{CR}_{\mathrm{B}}-\mathrm{CR}_{\mathrm{I}}\right) / \mathrm{CR}_{\mathrm{B}} \times 100 \\
& \text { Surface coverage }(\theta)=\mathrm{CR}_{\mathrm{B}}-\mathrm{CR}_{\mathrm{I}} / \mathrm{CR}_{\mathrm{B}}
\end{aligned}
$$

where $\mathrm{CR}_{\mathrm{B}}$ and $\mathrm{CR}_{\mathrm{I}}$ are Corrosion rates in the absence and presence of the inhibitors. 


\section{Potentiodynamic polarization method}

Potentiodynamic polarization measurements were carried out using electrochemical analyzer. The polarization measurements were made to evaluate the corrosion current, corrosion potential and tafel slopes. Experiments were carried out in a conventional three-electrode cell assembly with a time interval of $10-15$ minutes was given for each experiment to attain the steady state open circuit potential. The polarization was carried from a cathodic potential of $-800 \mathrm{mV}$ (vs SCE) to an anodic potential of $-200 \mathrm{mV}$ (Vs SCE) at a sweep rate of $1 \mathrm{mV}$ per second. The inhibitor efficiency was calculated using equation 4 below:

$$
\operatorname{IE~}(\%)=\frac{\mathrm{I}_{\text {Corr }}-\mathrm{I}^{*}{ }_{\text {Corr }}}{\mathrm{I}_{\text {Corr }}} \times 100
$$

where $\mathrm{I}_{\text {corr }}$ and $\mathrm{I}^{*}$ corr are corrosion current in the absence and presence of inhibitors.

\section{Electrochemical impedance method}

The electrochemical AC-impedance measurements were also performed using electrochemical analyzer. A sine wave with amplitude of $10 \mathrm{mV}$ was superimposed on the steady open circuit potential. The real part (Z') and the imaginary part (Z”) were measured at various frequencies in the range of $100 \mathrm{KHz}$ to $10 \mathrm{MHz}$. A plot of Z' vs Z' was made. From the plot, the charge transfer resistance $\left(R_{t}\right)$ was calculated and the double layer capacitance was then calculated using the equation 5 below:

$$
\mathrm{C}_{\mathrm{dl}}=\frac{1}{2 \pi} \mathrm{f}_{\max } \mathrm{R}_{\mathrm{t}}
$$

The experiments were carried out in the absence and presence of different concentrations of inhibitors. The percentage of inhibition efficiency was calculated using the equation 6 below:

$$
\operatorname{IE}(\%)=\frac{\mathrm{R}_{\mathrm{t}}^{*}-\mathrm{R}_{\mathrm{t}}}{\mathrm{R}_{\mathrm{t}}^{*}} \times 100
$$

where $\mathrm{R}_{\mathrm{t}}^{*}$ and $\mathrm{R}_{\mathrm{t}}$ are the charge transfer resistance in the presence and absence of inhibitors.

\section{Hydrogen permeation method}

The permeation current was measured using hydrogen permeation apparatus in $1 \mathrm{~N} \mathrm{HCl}$ medium in the absence and presence of optimum concentration of extracts.

\section{Surface examination studies}

Surface examination of mild steel specimens in the absence and presence of the optimum concentration of the extracts immersed for 3 hours at $30^{\circ} \mathrm{C}$ were studied with the magnification of $1000 \mathrm{X}$ specimens. The protective film formed on the surface of the mild steel was confirmed by scanning electron microscopy (SEM) studies.

\section{Weight loss studies}

\section{Results and Discussion}

The various corrosion parameters were obtained from weight loss method in $1 \mathrm{~N}$ hydrochloric acid in the absence and presence of various concentrations of the plant extracts ranging from $2 \%$ to $10 \% \mathrm{v} / \mathrm{v}$ are listed in Table 1 .

It was found that the optimum concentration for Adathoda vasica was found to be $6 \% \mathrm{v} / \mathrm{v}$ with maximum inhibition efficiency of $99.0 \%$, Eclipta alba at $8 \% \mathrm{v} / \mathrm{v}$ with maximum inhibition efficiency of $99.6 \%$ and Centella asiatica at $10 \% \mathrm{v} / \mathrm{v}$ with maximum inhibition efficiency of $85.3 \%$ for a period of 3 hours of immersion time. This result indicated that the plant extracts could act as good corrosion inhibitors. 


\section{Shyamala \& Arulanantham: A COMPARATIVE STUDY ON THE INHIBITORY ACTION OF SOME GREEN INHIBITORS ON THE CORROSION OF MILD STEEL IN HYDROCHLORIC ACID MEDIUM}

Table 1. Corrosion parameters obtained from weight loss measurements for mild steel in $1 \mathrm{~N} \mathrm{HCl}$ with various concentrations of the plant extracts

\begin{tabular}{lcccc}
\hline $\begin{array}{l}\text { Name of the Plant } \\
\text { Extract }\end{array}$ & $\begin{array}{c}\text { Conc. of } \\
\text { Extract } \\
\text { (\% in v/v) }\end{array}$ & $\begin{array}{c}\text { Corrosion } \\
\text { Rate } \\
\text { (mmpy) }\end{array}$ & $\begin{array}{c}\text { Inhibition } \\
\text { Efficiency (\%) }\end{array}$ & $\begin{array}{c}\text { Surface } \\
\text { Coverage ( } \boldsymbol{\theta})\end{array}$ \\
\hline Adathoda vasica & Blank & 30.67 & - & - \\
& 6.0 & 0.30 & 99.0 & $0.990^{*}$ \\
& 8.0 & 0.35 & 98.8 & 0.988 \\
Eclipta alba & 10.0 & 0.58 & 98.1 & 0.981 \\
& 6.0 & 0.98 & 96.8 & 0.968 \\
Centella asiatica & 8.0 & 0.12 & 99.6 & $0.996^{*}$ \\
& 10.0 & 0.12 & 99.6 & 0.996 \\
& 6.0 & 8.55 & 72.1 & 0.721 \\
& 8.0 & 6.56 & 78.6 & 0.786 \\
\hline
\end{tabular}

*Maximum inhibition efficiency

\section{Potentiodynamic polarization studies}

Potentiodynamic polarization studies as shown in Figures 1a - 1c revealed that the extracts act through mixed mode of inhibition as the polarization curves have not shifted towards more positive potential or more negative potential but has shifted towards less negative potential and lower current density values upon the addition of extract. It was observed that with increase in concentration of the plant extract from $2 \%$ to $10 \%$, the maximum inhibition efficiency of $99.2 \%$ was observed for Adathoda vasica at an optimum concentration of $6 \% \mathrm{v} / \mathrm{v}$, for Eclipta alba extract with $99.7 \%$ at $8 \% \mathrm{v} / \mathrm{v}$ and Centella asiatica with $85.7 \%$ at $10 \% \mathrm{v} / \mathrm{v}$ of the extract (Table 2 ).
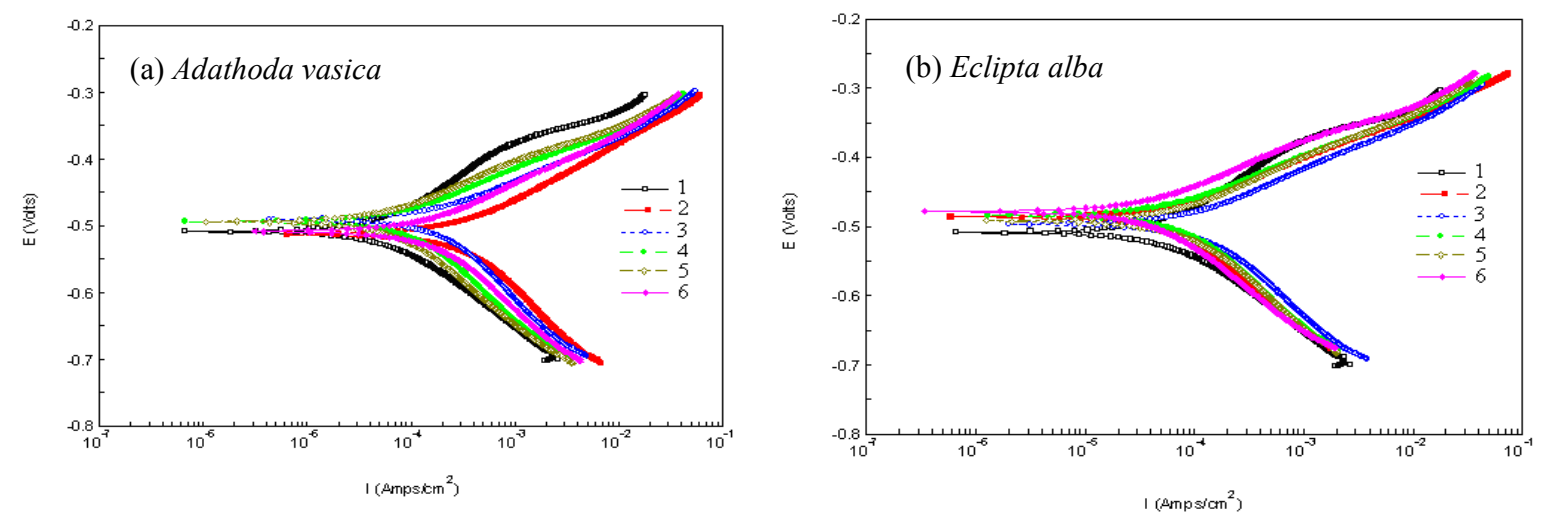


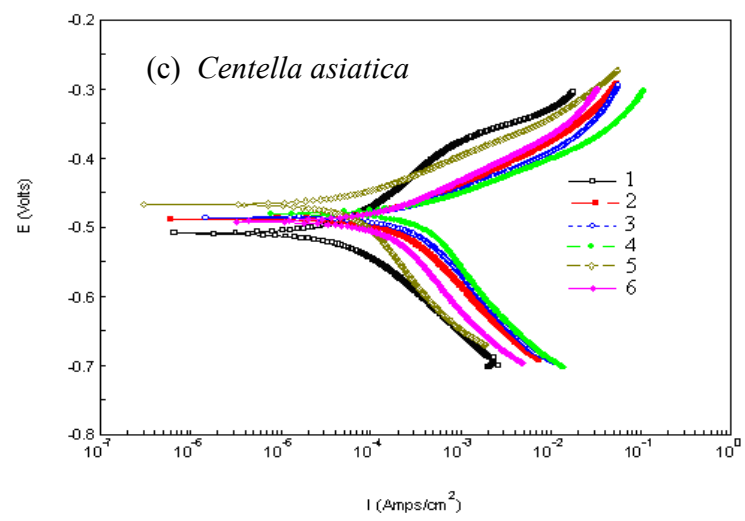

Figure 1. Potentiodynamic polarization curves for mild steel in $1 \mathrm{~N} \mathrm{HCl}$ solution in the absence and presence of various concentrations of the plant extracts (a) Adathoda vasica, (b) Eclipta alba and (c) Centella asiatica (Note legend information: 1 - blank, $2-2.0 \% \mathrm{v} / \mathrm{v}, 3-4.0 \% \mathrm{v} / \mathrm{v}, 4-6.0 \% \mathrm{v} / \mathrm{v}, 5-8.0 \% \mathrm{v} / \mathrm{v}$ and $6-10.0 \% \mathrm{v} / \mathrm{v})$

Table 2. Potentiodynamic polarization parameters for mild steel in $1 \mathrm{~N} \mathrm{HCl}$ at $30{ }^{\circ} \mathrm{C}$ containing various concentrations of the plant extracts

\begin{tabular}{|c|c|c|c|c|c|c|}
\hline \multirow[t]{2}{*}{ Name of the Plant Extract } & \multirow{2}{*}{$\begin{array}{l}\text { Conc. of } \\
\text { Extract } \\
(\% \text { in } v / v)\end{array}$} & \multirow{2}{*}{$\begin{array}{l}\mathbf{E}_{\text {corr }} \\
\text { (V) }\end{array}$} & \multirow{2}{*}{$\begin{array}{c}\mathbf{I}_{\text {corr }} \\
\left(\mathbf{m A} / \mathbf{c m}^{2}\right)\end{array}$} & \multicolumn{2}{|c|}{$\begin{array}{l}\text { Tafel Slope } \\
\text { mV/decade }\end{array}$} & \multirow{2}{*}{$\begin{array}{c}\text { Inhibition } \\
\text { Efficiency } \\
\quad(\%)\end{array}$} \\
\hline & & & & $\mathbf{b}_{\mathbf{a}}$ & $\mathbf{b}_{\mathbf{c}}$ & \\
\hline Blank & - & -0.510 & 3.57 & 78 & 122 & - \\
\hline Adathoda vasica & 6.0 & -0.493 & 0.02 & 74 & 120 & 99.2 \\
\hline Eclipta alba & 8.0 & -0.496 & 0.01 & 74 & 122 & 99.7 \\
\hline Centella asiatica & 10.0 & -0.492 & 0.51 & 76 & 124 & 85.7 \\
\hline
\end{tabular}

\section{Electrochemical impedance studies}

Impedance measurements were studied to evaluate the charge transfer resistance $\left(\mathrm{R}_{t}\right)$ and double layer capacitance $\left(\mathrm{C}_{\mathrm{dl}}\right)$ as shown in Table 3 and through these parameters the inhibition efficiency was calculated. From Figure 2, the obtained Impedance diagrams are almost in a semi-circular appearance, indicating that the charge - transfer process mainly controls the corrosion of mild steel. Deviations of perfect circular shape are often referred to the frequency dispersion of interfacial impedance. In fact, in the presence of the plant extracts the values of $R_{t}$ has enhanced and the values of double layer capacitance are also brought down to the maximum extent. The decrease in $\mathrm{C}_{\mathrm{dl}}$ shows that the adsorption of the inhibitors takes place on the metal surface in acidic solution. A good agreement is observed between the results of weight loss method and electrochemical methods (Potentiodynamic Polarization method and Impedance method) in the order: Eclipta alba $>$ Adathoda vasica $>$ Centella asiatica. 
Table 3. Impedance parameters for the corrosion of mild steel in $1 \mathrm{~N} \mathrm{HCl}$ in the absence and presence of various concentrations of the plant extracts at $30^{\circ} \mathrm{C}$

\begin{tabular}{lcccc}
\hline Name of the Plant Extract & $\begin{array}{c}\text { Conc. of Extract } \\
(\mathbf{\%} \text { in } \mathbf{v} / \mathbf{v})\end{array}$ & $\begin{array}{c}\mathbf{R}_{\mathbf{t}} \\
\left(\mathbf{\Omega} \mathbf{~ m}^{2}\right)\end{array}$ & $\begin{array}{c}\mathbf{C}_{\mathbf{d l}} \\
\left(\boldsymbol{\mu} \mathbf{F} / \mathbf{c m}^{2}\right)\end{array}$ & $\begin{array}{c}\text { Inhibition Efficiency } \\
(\mathbf{\%})\end{array}$ \\
\hline Rlank & - & 758 & 78524 & \\
Adathoda vasica & 6.0 & 285.23 & 7.65 & 97.3 \\
Eclipta alba & 8.0 & 358.80 & 6.00 & 97.9 \\
Centella asiatica & 10.0 & 54.32 & 39.88 & 86.0 \\
\hline
\end{tabular}
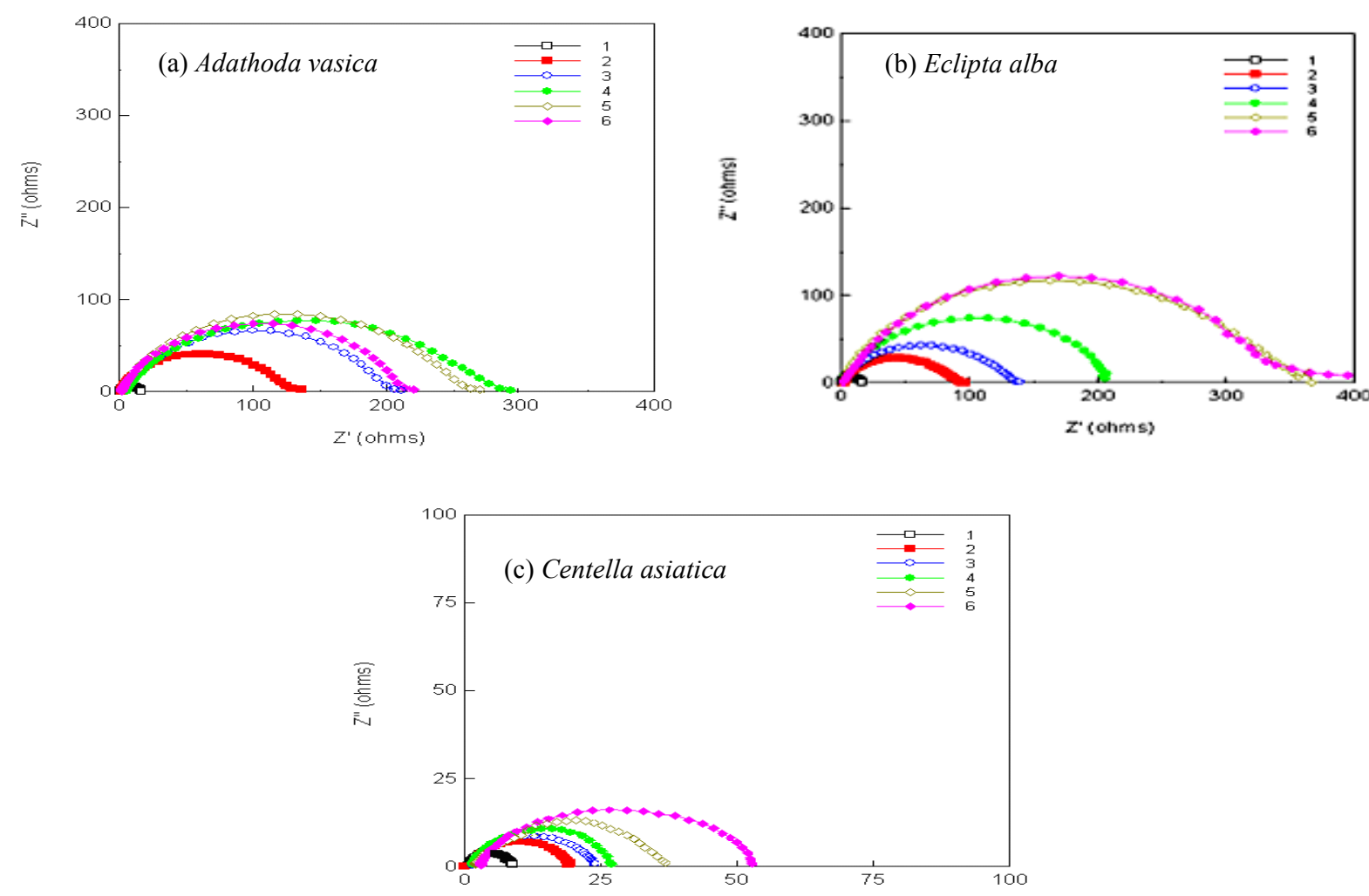

Figure 2. Impedance diagrams for mild steel in $1 \mathrm{~N} \mathrm{HCl}$ solution in the absence and presence of various concentrations of the plant extract: (a) Adathoda vasica, (b) Eclipta alba and (c) Centella asiatica. (Note legend information: 1 - blank, $2-2.0 \% \mathrm{v} / \mathrm{v}, 3-4.0 \% \mathrm{v} / \mathrm{v}, 4-6.0 \% \mathrm{v} / \mathrm{v}, 5-8.0 \% \mathrm{v} / \mathrm{v}$ and $6-$ $10.0 \% \mathrm{v} / \mathrm{v})$

\section{Kinetics and reason for the corrosion inhibition}

The major phytochemical constituents present in Adathoda vasica are the alkaloids namely vasicine and vasicinone (Figure 3), in Centella asiatica is asiaticoside, a triterpene glycoside (Figure 4), and in Eclipta alba are wedelolactone, $\beta$-sitosterol, stigmasterol (Figure $5 \mathrm{a}-5 \mathrm{c}$ ) and also an alkaloid namely ecliptine $[5,6]$. Inspection of the chemical structures of the phytochemical constituents reveals that the compounds can adsorb on the metal surface via the lone pair of electrons present on their oxygen atoms and make a barrier for charge and mass transfer leading to decrease the interaction of the metal with the corrosive environment. As a result, the corrosion rate of the 
metal was decreased. The formation of film layer essentially blocks discharge of $\mathrm{H}^{+}$and dissolution of metal ions. Due to electrostatic interaction, the protonated constituent's molecules are adsorbed (physisorption) and high inhibition is expected [1]. Acid pickling inhibitors containing organic $\mathrm{N}, \mathrm{S}$ and $\mathrm{OH}$ groups behave similarly to inhibit corrosion [7 - 10].

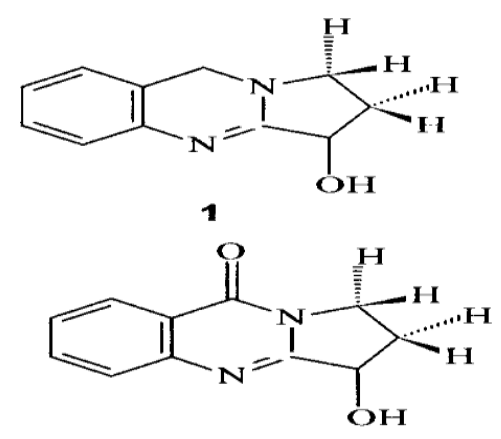

2

Figure 3. Chemical structure of (1) vasicine and (2) vasicinone

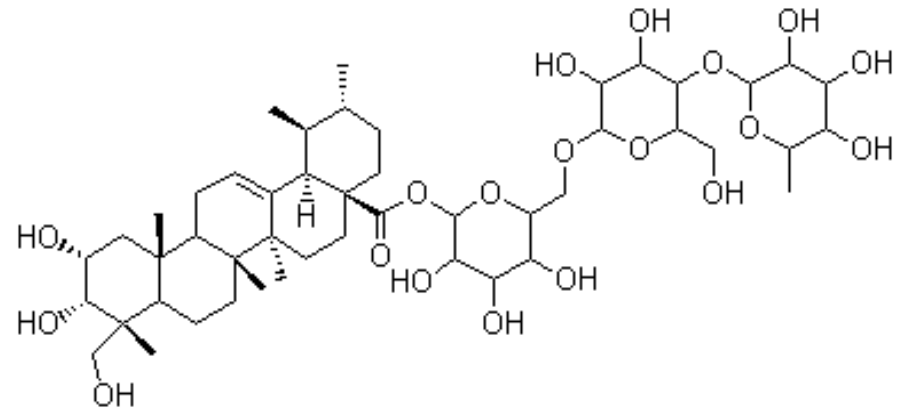

Figure 4. Chemical structure of asiaticoside

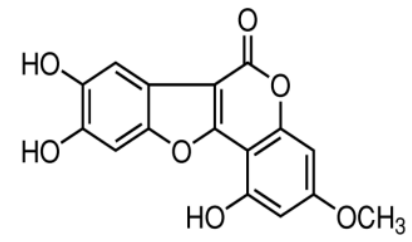

(a)

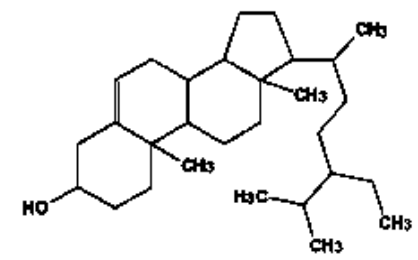

(b)

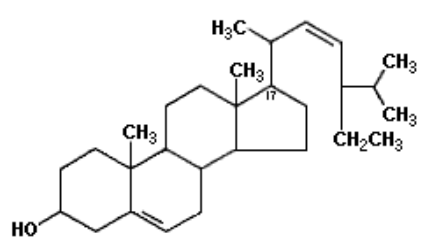

(c)

Figure 5. Chemical structure of (a) wedelolactone, (b) $\beta$-sitosterol and (c) stigmasterol

The adsorption of different concentrations of Adathoda vasica, Eclipta alba and Centella asiatica extracts on the surface of mild steel in $1 \mathrm{~N}$ hydrochloric acid followed Langmuir adsorption isotherm as shown in Figure 6. 


\section{Shyamala \& Arulanantham: A COMPARATIVE STUDY ON THE INHIBITORY ACTION OF SOME GREEN INHIBITORS ON THE CORROSION OF MILD STEEL IN HYDROCHLORIC ACID MEDIUM}
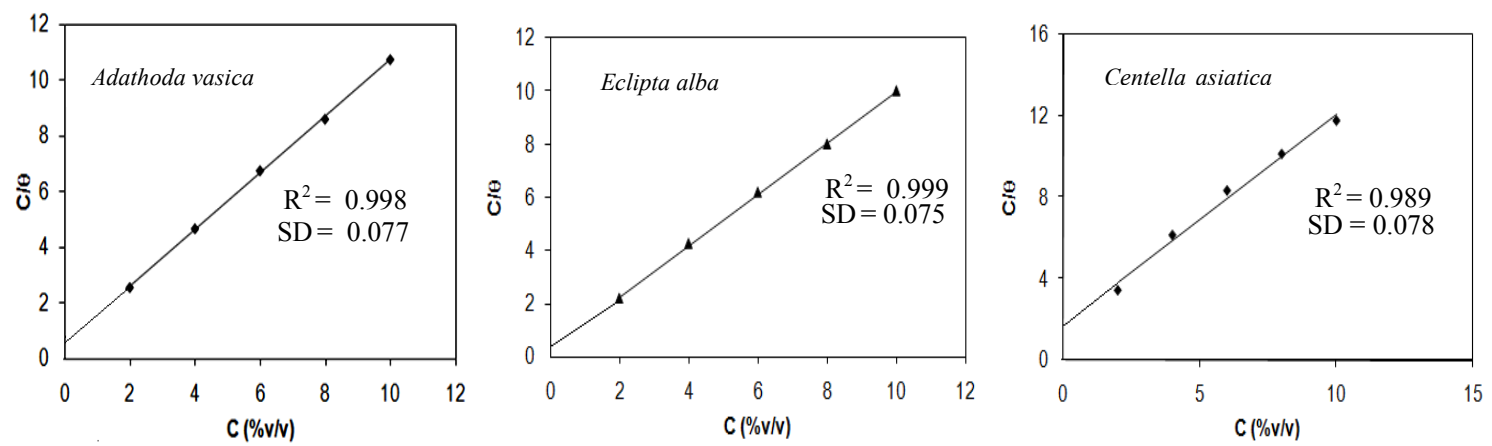

Figure 6. Langmuir adsorption isotherm plot for the adsorption of different concentrations of the green inhibitors on the surface of mild steel in $1 \mathrm{~N} \mathrm{HCl}$ solution

\section{Surface examination studies}

From the SEM images it shows the presence of a protective film over the surface of the mild steel in the presence of the inhibitors and the protective film is uniform in the order: Eclipta alba $>$ Adathoda vasica $>$ Centella asiatica. The SEM morphology of the adsorbed protective film on the mild steel surface has confirmed the high performance of inhibitive effect of the plant extracts as shown in Figures 7a to 7d, respectively.
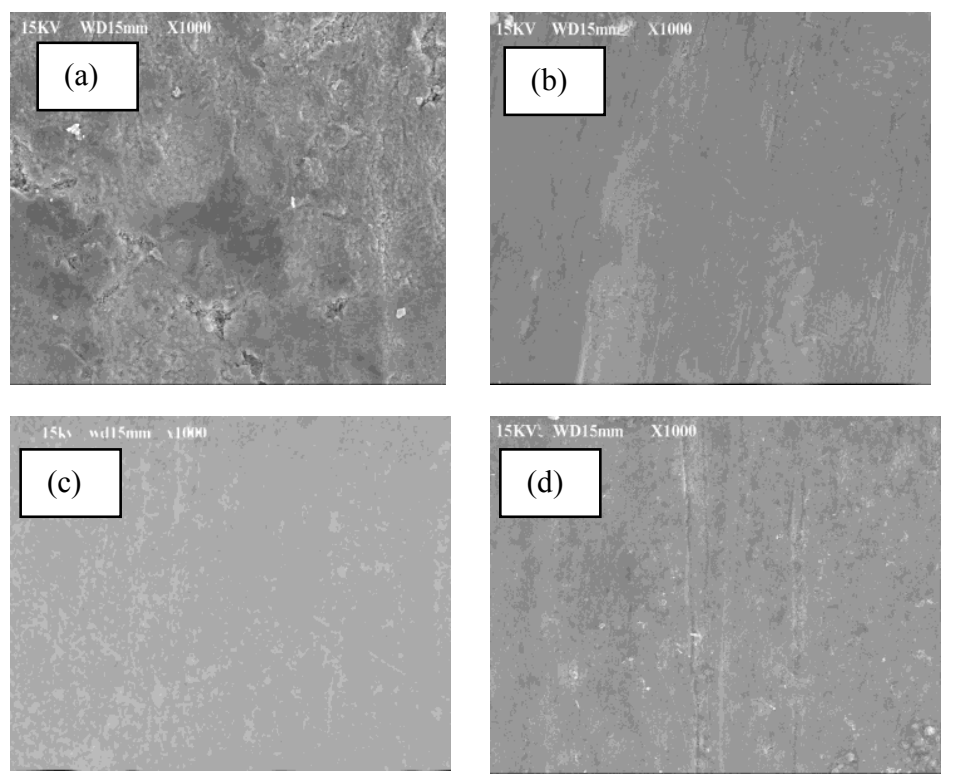

Figure 7. Mild steel immersed in $1 \mathrm{~N} \mathrm{HCl}$ solution (a) blank, (b) with optimum concentration ( $6 \% \mathrm{v} / \mathrm{v})$ of Adathoda vasica, (c) optimum concentration ( $8 \% \mathrm{v} / \mathrm{v})$ of Eclipta alba and optimum concentration $(10 \% \mathrm{v} / \mathrm{v})$ of Centella asiatica

From the hydrogen permeation studies on mild steel in $1 \mathrm{~N} \mathrm{HCl}$ in the absence and presence of inhibitors, it was observed that all the prepared extracts were able to reduce the permeation current compared to the control because 
those inhibitors, which reduce the permeation current are good at inhibiting the entry of hydrogen into the metal concerned. The decrease in the permeation current follows the order: Eclipta alba $>$ Adathoda vasica $>$ Centella asiatica. Permeation current vs. time curves for mild steel in $1 \mathrm{~N} \mathrm{HCl}$ in the absence and presence of inhibitors are shown in Figure 8 and their corresponding permeation are given in Table 5.

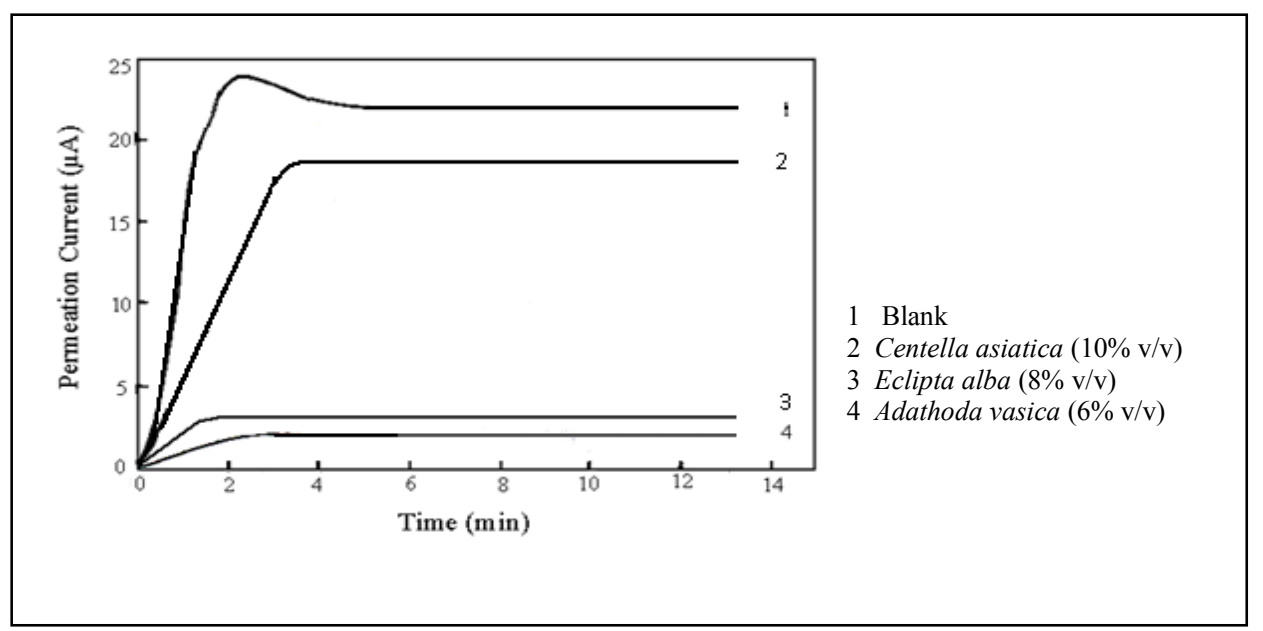

Figure 8. Hydrogen permeation current $v s$. time plots for mild steel in $1 \mathrm{~N} \mathrm{HCl}$ solution in the absence and presence of an optimum concentration of the plant extracts

Table 5. Hydrogen permeation current parameters in the absence and presence of inhibitors

\begin{tabular}{lccc}
\hline Inhibitor & $\begin{array}{c}\text { Conc. of the Extract } \\
(\% \mathbf{~ i n ~ v / v ) ~}\end{array}$ & $\begin{array}{c}\text { Permeation Current } \\
(\boldsymbol{\mu} \mathbf{A})\end{array}$ & $\begin{array}{c}\text { Reduction in Permeation } \\
\text { Current } \mathbf{( \% )}\end{array}$ \\
\hline Blank & - & 23.0 & - \\
Centella asiatica & 10.0 & 19.4 & 15.65 \\
Eclipta alba & 8.0 & 2.2 & 90.43 \\
Adathoda vasica & 6.0 & 3.1 & 86.52 \\
\hline
\end{tabular}

\section{Conclusion}

Green inhibitors namely Adathoda vasica, Eclipta alba and Centella asiatica were proved to be good and efficient inhibitors for corrosion of mild steel in $1 \mathrm{~N}$ hydrochloric acid. Potentiodynamic polarization studies revealed that the extracts act through mixed mode of inhibition. The impedance studies revealed that charge-transfer process mainly controls the corrosion of mild steel. The mechanism involved is the phytochemical constituents in the plant extracts have adsorbed on the metal surface forming a protective thin film layer preventing the discharge of $\mathrm{H}^{+}$ions and dissolution of metal ions and has prevented the small corrosion on the surface of the metal. The adsorption followed Langmuir adsorption isotherm. The SEM morphology confirmed the high performance of inhibitive effect of the green inhibitors. Results obtained in weight loss method were very much in good agreement with the electrochemical methods and hydrogen permeation method in the order: Eclipta alba $>$ Adathoda vasica $>$ Centella asiatica and among the three plant extracts studied, the maximum inhibition efficiency was found in Eclipta alba which showed $99.6 \%$ inhibition efficiency at $8.0 \% \mathrm{v} / \mathrm{v}$ concentration of the extract. 


\section{Shyamala \& Arulanantham: A COMPARATIVE STUDY ON THE INHIBITORY ACTION OF SOME GREEN INHIBITORS ON THE CORROSION OF MILD STEEL IN HYDROCHLORIC ACID MEDIUM}

\section{References}

1. Muthukrishnan, P., Saravana Kumar, K., Jeyaprabha, B. and Prakash, P. (2014). Anticorrosive activity of Kigelia pinnata leaves extract on mild steel in acidic media. Metallurgical and Materials Transactions A, 45: $4510-4524$.

2. Nazeer, A. A., Shalabi, K. and Fouda, A. S. (2015). Corrosion inhibition of carbon steel by Roselle extract in hydrochloric acid solution: Electrochemical and surface study. Research on Chemical Intermediates, 41(7): $4833-4850$.

3. Gülşen, A. (2012). Corrosion inhibition of mild steel by Laurus nobilis leaves extract as green inhibitor. Research on Chemical Intermediates, 38(7): 1311 - 1321.

4. Shalabi, K., Fouda, A. S., Elewady, G. Y. and El-Askalany, A. (2014). Adsorption and inhibitive properties of Phoenix dactylifera L. extract as a green inhibitor for aluminum and aluminum-silicon alloy in HCl. Protection of Metals and Physical Chemistry of Surfaces, 50(3): 420 - 431.

5. Herb Information (2015). Access from www.himalayahealthcare.com/herbfinder.

6. Bhargava, K. K. (1970). Himalaya herbal monograph. Indian Journal of Chemistry, 8: 664.

7. Anupama, K. K. and Abraham, J. (2013). Electroanalytical studies on the corrosion inhibition behavior of guava (Psidium guajava) leaves extract on mild steel in hydrochloric acid. Research on Chemical Intermediates, 39(9): $4067-4080$.

8. Al-Otaibia, M. S., Al-Mayoufa, Khana, M., Mousaa, A. A., Al-Mazroab, S. A and Alkhathlana, H. Z. (2014). Corrosion inhibitory action of some plant extracts on the corrosion of mild steel in acidic media, Arabian Journal of Chemistry, 7(3): 340 - 346.

9. Benali, O., Selles, C. and Salghi, R. (2014). Inhibition of acid corrosion of mild steel by Anacyclus pyrethrum L. extracts. Research on Chemical Intermediates, 40(1): 259 - 268.

10. Patel, N. S., Jauhariand, S., Mehta, G. N., Al-Deyab, S. S., Warad, I., and Hammouti, B. (2013). Mild steel corrosion inhibition by various plant extracts in $0.5 \mathrm{M}$ sulphuric acid. International Journal of Electrochemical Science, 8: 2635 - 2655. 